\title{
The Effect of High Pressure and Subzero Temperature on Gelation of Washed Cod and Salmon Meat
}

\author{
Edyta Malinowska-Pańczyk* and Ilona Kołodziejska \\ Department of Food Chemistry, Technology and Biotechnology, Chemical Faculty, \\ Gdansk University of Technology, G. Narutowicza 11/12, PL-80-233 Gdańsk, Poland
}

Received: July 6, 2016

Accepted: June 27, 2017

\begin{abstract}
Summary
The objective of the present work is to examine the influence of pressure up to $193 \mathrm{MPa}$ at subzero temperature (without freezing of water) on myofibrillar proteins of salmon and cod meat and on the properties of gels obtained from washed mince of these fish. The solubility of proteins from myofibrils of cod and salmon meat suspended in $100 \mathrm{mM} \mathrm{KCl} \mathrm{solu-}$ tion increased after treating the samples with pressure above $60 \mathrm{MPa}$. The results of SDS-PAGE analysis showed that under these conditions two myosin light chains, tropomyosin and troponin $\mathrm{T}$ were released from myofibrils. The solubility of proteins in $0.9 \mathrm{M} \mathrm{NaCl}$ solution of washed fish meat after pressure treatment at $60 \mathrm{MPa}$ and $-5{ }^{\circ} \mathrm{C}$ decreased to about $80-90 \%$ and at $193 \mathrm{MPa}$ and $-20{ }^{\circ} \mathrm{C}$ to $60 \%$. Pressurization of cod meat decreased only slightly the solubility of proteins in SDS and urea solution and the solubility of salmon meat was similar to that in the unpressurized sample. There were no differences in the electrophoretic pattern of proteins from untreated and pressurized cod and salmon meat in the range of 60 to $193 \mathrm{MPa}$ and -5 to $-20^{\circ} \mathrm{C}$. The pressure treatment of washed salmon and cod meat at a temperature below $0{ }^{\circ} \mathrm{C}$ induced gelation; on the other hand, hardness of gels was lower by 28 and $26 \%$, respectively, than that of gels formed by heating. The salmon and cod gels pressurized at $193 \mathrm{MPa}$ and $-20{ }^{\circ} \mathrm{C}$ and then heated were much harder than only pressurized or heated gels.
\end{abstract}

Key words: high pressure processing, subzero temperature, washed cod and salmon meat, gelation, properties of myofibrillar proteins

\section{Introduction}

Numerous studies have been carried out on high-pressure effect on the properties of muscle proteins. High pressure treatment exerts conformational changes in myofibrillar proteins that can lead to their depolymerisation and solubilisation, denaturation and aggregation depending on the $\mathrm{pH}$, concentration and type of salt present, as well as parameters of the process (1-10).

From research and practical point of view, close attention is drawn to the pressure-induced gelation of fish myofibrillar proteins $(3,7,11-16)$. This process was proposed as an alternative to traditional heat-induced gelation in preparation of different gel-based products from surimi and fish paste. The mechanism of pressure-induced denaturation/gelation is considered to be a complex process in which rearrangement and/or destruction of non-covalent bonds of the tertiary structure of proteins take place $(10,15)$. The contribution of hydrogen bonds, hydrophobic interactions and electrostatic bonds in pressure-induced gels was evidenced $(13,17)$. Furthermore, using differential scanning calorimetry (DSC), Angsupanich and Ledward (18) observed that after pressurization of cod meat at $100-800 \mathrm{MPa}$ a new, quite stable structure stabilized by hydrogen bonds was formed. It was also found that covalent disulphide bonds at pressure higher than $300 \mathrm{MPa}$ could stabilize the gel network $(17,19)$.

\footnotetext{
*Corresponding author: Phone: +48 58347 2656; Fax: +48 58347 2694; E-mail: edyta.malinowska-panczyk@pg.gda 
Gels formed by pressure treatment have improved some rheological properties when compared to heat-induced gels $(13,20)$. Furthermore, the thermal gelation ability of muscle proteins may be enhanced by pressurization prior to heating $(3,4,21)$. The properties of fish gels obtained by using high pressure depend on fish species, state of proteins, activity of endogenic proteases and transglutaminase $(11,14,21,22)$. An important parameter affecting the properties of the formed gel is the temperature at which pressure treatment is applied $(13,16)$. Fish protein gels with good properties may be formed by pressure treatment at refrigeration temperatures $(13,20)$. Lowering of pressurization temperature below $0{ }^{\circ} \mathrm{C}$ increases the denaturation stage of myofibrilar proteins (23) and may affect their functional properties. Therefore, it is very interesting to study if gelation of fish proteins induced by pressure is also possible at such low temperature as -20 ${ }^{\circ} \mathrm{C}$ (in unfrozen system). Currently there is no literature data available on experiments conducted under these conditions. Understanding the impact that such high-pressure/low-temperature conditions exert on washed fish meat will create new opportunities in designing new products with improved functional properties and new direction in the development of fish surimi technology.

The objective of the present work is to examine the influence of pressure up to $193 \mathrm{MPa}$ at subzero temperature (without freezing of water) on the myofibrillar proteins of salmon and cod meat and on the properties of gels from washed mince of these fish. The properties of gels formed by pressure treatment followed by heating were also studied. Gels induced by conventional heating were used as controls.

\section{Materials and Methods}

\section{Preparation of washed meat and gels}

Fresh filets of cod (Gadus morhua) and salmon (Salmo salar) were purchased on a local market in Gdynia, Poland. They were skinned and minced in a meat grinder $(\phi$ (mesh) $=3 \mathrm{~mm}$, model 986.86 Zelmer; Zelmer S.A., Rzeszów, Poland). The mince was washed twice by mixing it with water $\left(1: 3\right.$, by mass per volume) for $15 \mathrm{~min}$ at $0{ }^{\circ} \mathrm{C}$ and centrifuged at $5000 \times g$ (MPW 350R centrifuge; MPW Med. Instruments, Warsaw, Poland) for $30 \mathrm{~min}$ at $4{ }^{\circ} \mathrm{C}$. Next, $0.15 \mathrm{M} \mathrm{NaCl}$ solution (Polish Chemical Reagents SA, Gliwice, Poland) was added to the washed meat (1:3, by mass per volume). The resulting slurry was mixed for $15 \mathrm{~min}$ at $0{ }^{\circ} \mathrm{C}$ and centrifuged at $5000 \times g$ for $30 \mathrm{~min}$ at 4 ${ }^{\circ} \mathrm{C}$. Sodium chloride $(2.5 \%$, by mass; Polish Chemical Reagents SA) and crumbled ice were added to prepare a batter with the required final gel moisture of $78 \%$. The mixture was blended for $15 \mathrm{~min}$. The temperature of the mixture did not exceed $10{ }^{\circ} \mathrm{C}$. The prepared batters were filled into flexible plastic casings (Podanfol S.A., Chodzież, Poland) of $35 \mathrm{~mm}$ in diameter. The filled casings (100 mm length) were subjected to pressure of $193 \mathrm{MPa}$ at $-20{ }^{\circ} \mathrm{C}$ and in some cases heated in water bath to achieve $90{ }^{\circ} \mathrm{C}$ in the core of the sample and kept under these conditions for $15 \mathrm{~min}$ (total heating time was about $50 \mathrm{~min}$ ). Gels induced only by heating (conventional gelling procedure) were made by a setting step at $25^{\circ} \mathrm{C}$ for $60 \mathrm{~min}$, followed by heating $\left(90^{\circ} \mathrm{C}\right.$ for $\left.15 \mathrm{~min}\right)$. After cooking, all samples were cooled in $10-15^{\circ} \mathrm{C}$ running water and stored overnight at $4{ }^{\circ} \mathrm{C}$ before analysis.

\section{Isolation of myofibrils}

Minced meat was homogenized for $5 \mathrm{~s}$ at $7000 \mathrm{rpm}$ followed by $20 \mathrm{~s}$ at $12000 \mathrm{rpm}$ using Silent Crusher M D-91126 (Heidolph Instruments GmbH \& Co, Schwabach, Germany) with six volumes of buffer (20 mM Tris- $\mathrm{HCl}$, $100 \mathrm{mM} \mathrm{KCl}, 5 \mathrm{mM}$ EDTA, pH=7.6; Merck Millipore, Darmstadt, Germany) and centrifuged at $4000 \times g$ (MPW 350R centrifuge; MPW Med. Instruments) for 15 min at 4 ${ }^{\circ} \mathrm{C}$. The pellets were resuspended in six volumes of the buffer, blended for $2 \mathrm{~min}$ and subsequently centrifuged at $4000 \times g$ for $15 \mathrm{~min}$ at $4{ }^{\circ} \mathrm{C}$. These operations were repeated five times. The final pellets were resuspended in six volumes of buffer and homogenized for $15 \mathrm{~s}$ at $7000 \mathrm{rpm}$ and centrifuged at $4000 \times g$ for $15 \mathrm{~min}$ at $4{ }^{\circ} \mathrm{C}$. The same operations were repeated twice. The homogenate was filtered through a mesh nylon net $(20 \mu \mathrm{m}$ pore size; Merck Millipore) and centrifuged at $1000 \times g$ for $10 \mathrm{~min}$ at $4{ }^{\circ} \mathrm{C}$ and washed with the same buffer in order to remove the connective tissue. The pellets were resuspended in $100 \mathrm{mM}$ $\mathrm{KCl}$ and homogenized at $7000 \mathrm{rpm}$ for $15 \mathrm{~s}$. The biuret method was used to determine protein concentration (24). The final concentration of protein was adjusted to $5 \mathrm{mg} /$ $\mathrm{mL}$. The samples were transferred to glass tubes, closed with stoppers without leaving any air bubbles inside, and kept for $10-15 \mathrm{~min}$ at $0{ }^{\circ} \mathrm{C}$ before pressurization.

\section{Pressure treatment}

Pressurization was carried out at 60,110 and $193 \mathrm{MPa}$ at $-5,-10$ and $-20{ }^{\circ} \mathrm{C}$, respectively, as described by Malinowska-Pańczyk et al. (23). The samples and a metal spring were placed in a cylindrical metal vessel filled with water and closed without leaving any air bubbles inside. The pressure vessel was gradually immersed with the closed side down in a cooling bath at the appropriate temperature. Pressure was generated as a result of increasing the volume of the forming ice I in a sealed vessel filled with water and kept at temperatures below $0{ }^{\circ} \mathrm{C}$. The increase of pressure up to $207 \mathrm{MPa}$ causes lowering of the freezing point of water to $-22{ }^{\circ} \mathrm{C}(25)$. After pressurization the vessel was warmed in the upper part to $15^{\circ} \mathrm{C}$ and placed for a few minutes in a water bath at $20{ }^{\circ} \mathrm{C}$. The whole process, including pressurization and decompression steps, lasted $50 \mathrm{~min}(40+10 \mathrm{~min})$.

\section{Solubility test of myofibrillar proteins in salt solutions}

To test the solubility of myofibrilar proteins in salt solution, pressurized and unpressurized samples of myofibrils in $100 \mathrm{mM} \mathrm{KCl}$ were centrifuged at 4000×g (MPW 350R centrifuge; MPW Med. Instruments) for 15 min at 4 ${ }^{\circ} \mathrm{C}$. Biuret method was used to determine protein concentration in the supernatant (24).

The solubility of washed meat proteins in $0.9 \mathrm{M} \mathrm{NaCl}$ solution was assayed according to Malinowska-Pańczyk et al. (23). Samples were homogenized for $5 \mathrm{~s}$ at $7000 \mathrm{rpm}$ followed by $30 \mathrm{~s}$ at $12000 \mathrm{rpm}$ using Silent Crusher M D-91126 (Heidolph Instruments $\mathrm{GmbH} \& \mathrm{Co}$ ). The homogenate was centrifuged at $4500 \times g$ for $30 \mathrm{~min}$ at $4{ }^{\circ} \mathrm{C}$ and the protein concentration in the supernatant was determined using biuret method (24). 


\section{Solubility of proteins in a solution containing SDS and urea with or without $\beta$-mercaptoethanol}

Untreated and meat samples treated at $193 \mathrm{MPa}$ were mixed with $20 \mathrm{mM}$ Tris- $\mathrm{HCl}$ buffer (1:9 by mass per volume, $\mathrm{pH}=8$ ) and homogenized for $3 \mathrm{~s}$ at $700 \mathrm{rpm}$ (Silent Crusher M D-91126; Heidolph Instruments GmbH \& Co) and for $30 \mathrm{~s}$ at $12000 \mathrm{rpm}$. The homogenates were divided into two parts. Solution I (2\% SDS, $8 \mathrm{M}$ urea, $20 \mathrm{mM}$ buffer Tris- $\mathrm{HCl}, \mathrm{pH}=8$; Merck Millipore) was added to the first part, and solution II (2\% SDS, $8 \mathrm{M}$ urea, $2 \%$ $\beta$-mercaptoethanol, $20 \mathrm{mM}$ Tris- $\mathrm{HCl}$ buffer, $\mathrm{pH}=8$; Merck Millipore) was added to the second part (1:1 by volume). The mixtures were transferred to Nalgene ${ }^{\mathrm{TM}}$ (Thermo Scientific, Waltham, MA, USA) plastic tubes, purged with nitrogen, capped, heated at $100{ }^{\circ} \mathrm{C}$ for $2 \mathrm{~min}$, and agitated constantly overnight at ambient temperature. The samples were subsequently centrifuged at 2000 $\times g$ (MPW 350R centrifuge; MPW Med. Instruments) for $5 \mathrm{~min}$. Protein in the supernatant was determined using $\mathrm{RC} \mathrm{DC}{ }^{\mathrm{TM}}$ protein assay kit (Bio-Rad, Hercules, CA, USA). Protein in meat was determined using Kjeldahl method (26).

\section{SDS-PAGE electrophoresis}

Electrophoresis was performed in accordance with Laemmli (27). Samples of washed meat and soluble fractions of myofibrils were dissolved in $0.125 \mathrm{M}$ Tris- $\mathrm{HCl}$, $4 \%$ SDS, $20 \%$ (by volume) glycerol, $0.2 \mathrm{M}$ dithiothreitol and $0.02 \%$ Bromophenol Blue (all from Merck Millipore) $(\mathrm{pH}=6.8)$ and heated at $100{ }^{\circ} \mathrm{C}$ for $1 \mathrm{~min}$. A volume of 30 $\mu \mathrm{L}$ of samples was placed on the $4 \%$ stacking gel. Separation was performed on $12 \%$ gel. Molecular mass standard from 250 to $10 \mathrm{kDa}$ (HyperPage II Prestained Protein Marker, Bioline Reagents Ltd, London, UK) was used as a reference. Samples were separated on the Hoefer SE660 (Hoefer Inc, Holliston, MA, USA) vertical electrophoresis system.

\section{Texture profile analysis and penetration test}

Texture profile analysis (TPA) of the samples prepared as described in paragraph Preparation of washed meat and gels was performed in a universal testing machine (model 5543; Instron Engineering Corp., Canton, MA, USA) as described by Bourne (28). The gels were removed from their castings and cut to $3.0-\mathrm{cm}$ height. Before analysis, the samples were tempered for $1 \mathrm{~h}$ at room temperature. Compression was applied using a flat plunger (a cylindrically shaped piston; $50 \mathrm{~mm}$ diameter) at the deformation rate of $2 \mathrm{~mm} / \mathrm{s}$. The samples were compressed in two consecutive cycles to $50 \%$ of their initial height. The TPA parameters (hardness, springiness, cohesiveness and chewiness) were determined according to Mochizuki (29).

In the puncture test, the gels were penetrated to the breaking point using the equipment as above with a round-ended stainless steel plunger $(d=5 \mathrm{~mm}$, model 5543; Instron Engineering Corp., Canton, MA, USA). Cross-head speed was $10 \mathrm{~mm} / \mathrm{min}$ and a 10 -load cell was used. The gel strength was calculated by multiplying breaking force (in $\mathrm{N}$ ) with breaking deformation (in $\mathrm{mm}$ ) determined from the force-deformation curves.

\section{Folding test}

The folding test was performed according to Lee (30). A slice ( $d=3.5 \mathrm{~cm}, h=3 \mathrm{~mm}$ ) was folded over twice and the extent of its folding or crack formation were measured. The score was: $\mathrm{AA}=\mathrm{does}$ not crack when folded twice, $\mathrm{A}=\mathrm{does}$ not crack when folded once but cracks after two foldings, $\mathrm{B}=$ gradually cracks after being folded once, $\mathrm{C}=$ cracks immediately after first folding, and $\mathrm{D}=$ breakable by finger pressure without folding.

\section{Statistical analysis}

The results of solubility tests are presented as average values of at least six replications with standard deviation. Texture profile analysis parameters, gel strength and gel forming ability show the average values and standard deviation of at least eight replicates. Analysis of variance (one-way procedure) was performed to evaluate the differences between treatments using the Statistica v. 8.0 (31).

\section{Results and Discussion}

\section{Protein solubility in salt solutions}

The solubility of proteins from isolated fish myofibrils suspended in $100 \mathrm{mM} \mathrm{KCl}$ solution increased after treating the samples with pressure of 60,110 and $193 \mathrm{MPa}$ at $-5,-10$ and $-20{ }^{\circ} \mathrm{C}$, respectively. The content of dissolved proteins from salmon and cod myofibrils treated with pressure of $193 \mathrm{MPa}$ was higher by about 2 and 1.5 times respectively than of those in the unpressurized samples (Table 1). This phenomenon has been observed in pressure-treated suspension of myofibrils isolated from sheep muscle (1), rabbit (32) and bovine muscle (8). Suzuki et al. (32) suggested that pressurization of isolated myofibrils lead to depolimerization of actomyosin, myosin polymer and F-actin, while McArthur and Wilding (33) supposed that hydrophobic interactions, which can probably participate in stabilization of myofibrils, are disrupted by pressure and consequently could lead to their increased solubility in low-ionic-strenght solutions.

Solubilisation of myofibrillar proteins in $100 \mathrm{mM} \mathrm{KCl}$ solution induced by pressure was confirmed by SDS-PAGE. Two myosin light chains, tropomyosin, troponin T and actin were released from myofibrils pressurized at 60 and $110 \mathrm{MPa}$ (Fig. 1). Suzuki et al. (32) observed that also troponin $\mathrm{I}$ and $\mathrm{C}$, and $\mathrm{M}$ protein were present in the supernatant obtained from the suspension of rabbit skeletal

Table 1 . The solubility of proteins isolated from myofibrils of cod and salmon meat pressurized in $100 \mathrm{mM} \mathrm{KCl}$ solution

\begin{tabular}{ccc}
\hline \multirow{2}{*}{$p / \mathrm{MPa}$} & \multicolumn{2}{c}{$\gamma($ protein $) /(\mathrm{mg} / \mathrm{mL})$} \\
\cline { 2 - 3 } & \multicolumn{1}{c}{$\operatorname{Cod}$} & Salmon \\
\hline 0.1 & $(0.19 \pm 0.02)^{\mathrm{a}}$ & $(0.29 \pm 0.07)^{\mathrm{a}}$ \\
60 & $(0.34 \pm 0.08)^{\mathrm{b}}$ & $(0.27 \pm 0.09)^{\mathrm{a}}$ \\
111 & $(0.38 \pm 0.084)^{\mathrm{b}}$ & $(0.40 \pm 0.02)^{\mathrm{b}}$ \\
193 & $(0.43 \pm 0.07)^{\mathrm{b}}$ & $(0.40 \pm 0.01)^{\mathrm{b}}$ \\
\hline
\end{tabular}

The results are expressed as mean value \pm standard deviation (S.D.), $N=6$; values in a particular column followed by different letters differ significantly $(\mathrm{p}<0.05)$ 


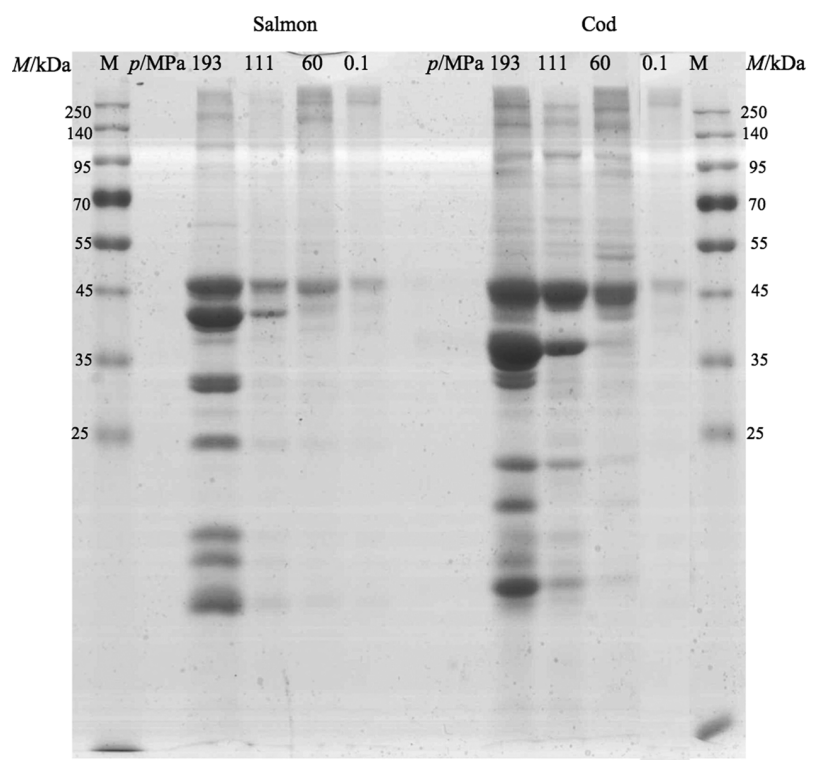

Fig. 1. SDS-PAGE profiles of soluble proteins from myofibrils pressurized in $100 \mathrm{mM} \mathrm{KCl}$ solution. $\mathrm{M}=$ markers

muscle myofibrils pressurized at $150 \mathrm{MPa}$. Increase of pressure up to $200 \mathrm{MPa}$ caused slight solubility of myosin heavy chain, while solubility of troponin I decreased. Furthermore, the same authors found that the content of myosin heavy chain increased significantly when pressure of $300 \mathrm{MPa}$ was used. However, Jung et al. (8) reported mainly the increase in the solubility of two myosin light chains of bovine myofibrils treated with pressure above $100 \mathrm{MPa}$. However, both papers showed that the pressure-induced changes in the ultrastructure of myofibrils could be responsible for releasing particular proteins.

It has been shown that changes in myofibrillar protein solubility differ depending on whether the isolated myofibrils or whole meat is pressurized $(32,33)$. Such differences have also been observed in this work. The solubility of proteins in $0.9 \mathrm{M} \mathrm{NaCl}$ solution of washed salmon and cod meat pressurized at $60 \mathrm{MPa}$ decreased to about $80-90 \%$ and at $193 \mathrm{MPa}$ and $-20{ }^{\circ} \mathrm{C}$ down to $60 \%$, indicating that under these conditions denaturation of proteins takes place (Fig. 2). Similar results were obtained previously for unwashed cod and salmon meat (23). The loss of protein solubility in salt solutions was observed also after pressurization of Norway lobster (Nephrops norvegicus) meat at $200 \mathrm{MPa}$ and $5{ }^{\circ} \mathrm{C}$ and at $-20{ }^{\circ} \mathrm{C}$ (in the

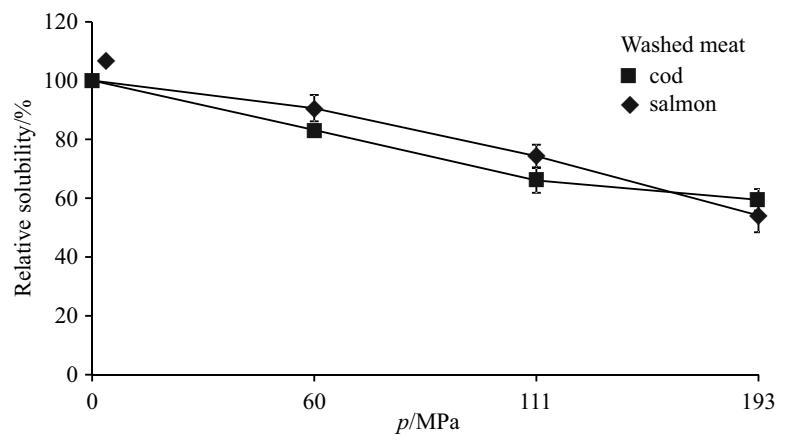

Fig. 2. The solubility of washed cod and salmon meat proteins in $0.9 \mathrm{M} \mathrm{NaCl}$ solutions after treatment at $60-193 \mathrm{MPa}$ pressure-shift freezing process) (2), as well as in paste from arrowtooth flounder (Atheresthes stomias) pressurized at 400 and $600 \mathrm{MPa}(3,4)$. Mammalian proteins and those of fish living in tropical waters are more resistant to denaturation/aggregation induced by pressure $(7,9,23,34,35)$. A similar relationship is observed in the thermal process. It has been found that the thermal stability translates into pressure stability. The greater pressure and thermal stability of proteins from warm-adapted species than that from those adapted to cold habitats results from differences in their molecular structures (36).

\section{Solubility of proteins in SDS solutions and SDS-PAGE analysis}

Pressure treatment of washed cod meat only slightly decreased the solubility of proteins in SDS and urea solution, and the solubility of washed salmon meat was similar to the control (Table 2). These results indicate that a pressure of $193 \mathrm{MPa}$ at subzero temperature does not cause covalent bond formation, including disulphide linkages, therefore $100 \%$ of protein solubility in SDS and urea solution containing $\beta$-mercaptoethanol was achieved. Montero et al. (22) also reported that disulphide bonds do not participate significantly in the pressure-induced (300 MPa) aggregation of Atlantic horse mackerel (Trachurus trachurus) proteins. Similar results were obtained with pressurized gels from tilapia meat pastes (36). On the other hand, Gilleland et al. (17) showed that pressure treatment at 300 $\mathrm{MPa}$ and $5{ }^{\circ} \mathrm{C}$ of surimi paste from Alaska pollock (Theragra chalcogramma) decreased protein solubility in SDS and urea solution from $90 \%$ (the untreated sample) to about $40 \%$. After including $\beta$-mercaptoethanol into the solubilizing medium, the sample was thoroughly solubilized, indicating that all these covalent bonds formed in pressurized paste corresponded to disulphide bonds. Only when incubation of the sample at $25{ }^{\circ} \mathrm{C}$ preceded the pressure treatment, the solubility in the presence of $\beta$-mercaptoethanol was lower. According to the authors, forming of $\varepsilon$-( $\gamma$-glutamyl)lysine bonds by transglutaminase was responsible for the decrease of protein solubility under these conditions.

Table 2. The solubility of washed cod and salmon proteins in SDS/urea solution with or without $\beta$-mercaptoethanol unpressurized and pressurized at $193 \mathrm{MPa}$

\begin{tabular}{lcccc}
\hline Solution & \multicolumn{4}{c}{ Solubility/\% } \\
\cline { 2 - 5 } & \multicolumn{4}{c}{ Cod } \\
\cline { 2 - 5 } & 0.1 & 193 & 0.1 & 193 \\
\hline & $87.6^{\mathrm{a}}$ & $82.2^{\mathrm{b}}$ & $73.9^{\mathrm{a}}$ & $74.0^{\mathrm{a}}$ \\
SDS/urea & $100^{\mathrm{a}}$ & $100^{\mathrm{a}}$ & $100^{\mathrm{a}}$ & $100^{\mathrm{a}}$ \\
\hline
\end{tabular}

The results are expressed as mean values, $N=6$; values in a particular row followed by different letters differ significantly $(p<0.05)$. SDS=sodium dodecyl sulphate

Figs. 3 and 4 show electrophoretic profiles of proteins from the untreated and pressurized washed meat samples. They differ slightly depending on the kind of tested meat. However, there were no differences in the electro- 


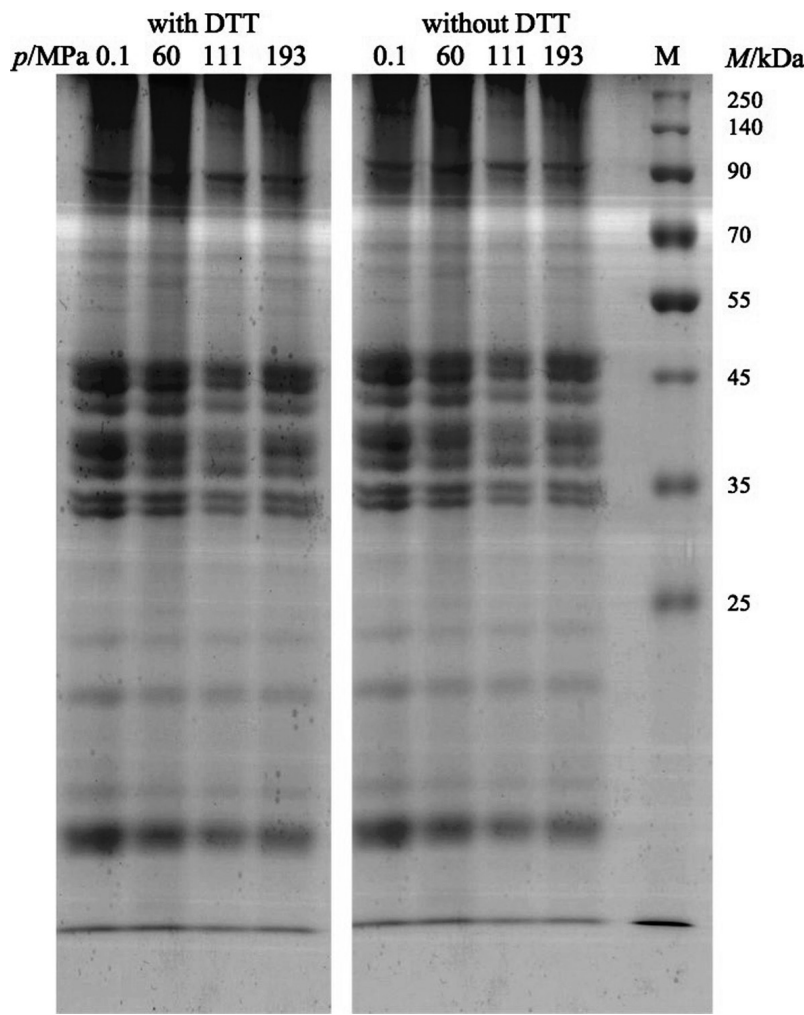

Fig. 3. SDS-PAGE profile of pressurized washed cod meat proteins; $\mathrm{M}=$ markers, DTT=dithiothreitol

phoretic pattern between the untreated and pressurized samples of particular meat. The results also show that disulphide bonds in meat proteins are not formed under these conditions. Angsupanich et al. (19), using SDS-PAGE, found that disulphide bonds participate in aggregation of myosin in myofibrils pressurized at above $600 \mathrm{MPa}$ isolated from turkey and cod meat but not at 200-400 MPa. Furthermore, some literature data show that enzymatic degradation of proteins is not excluded during pressure treatment of fish and mammalian meat $(5,6,22)$. However, such degradation did not appear in the samples of salmon and cod meat pressure-treated at below $0{ }^{\circ} \mathrm{C}$ (Figs. 3 and 4). If proteolytic enzymes are responsible for the degradation and if this reaction takes place during pressurization, our results can be easily explained: the temperature of $-20^{\circ} \mathrm{C}$ during pressure treatment is too low for enzymatic reaction.

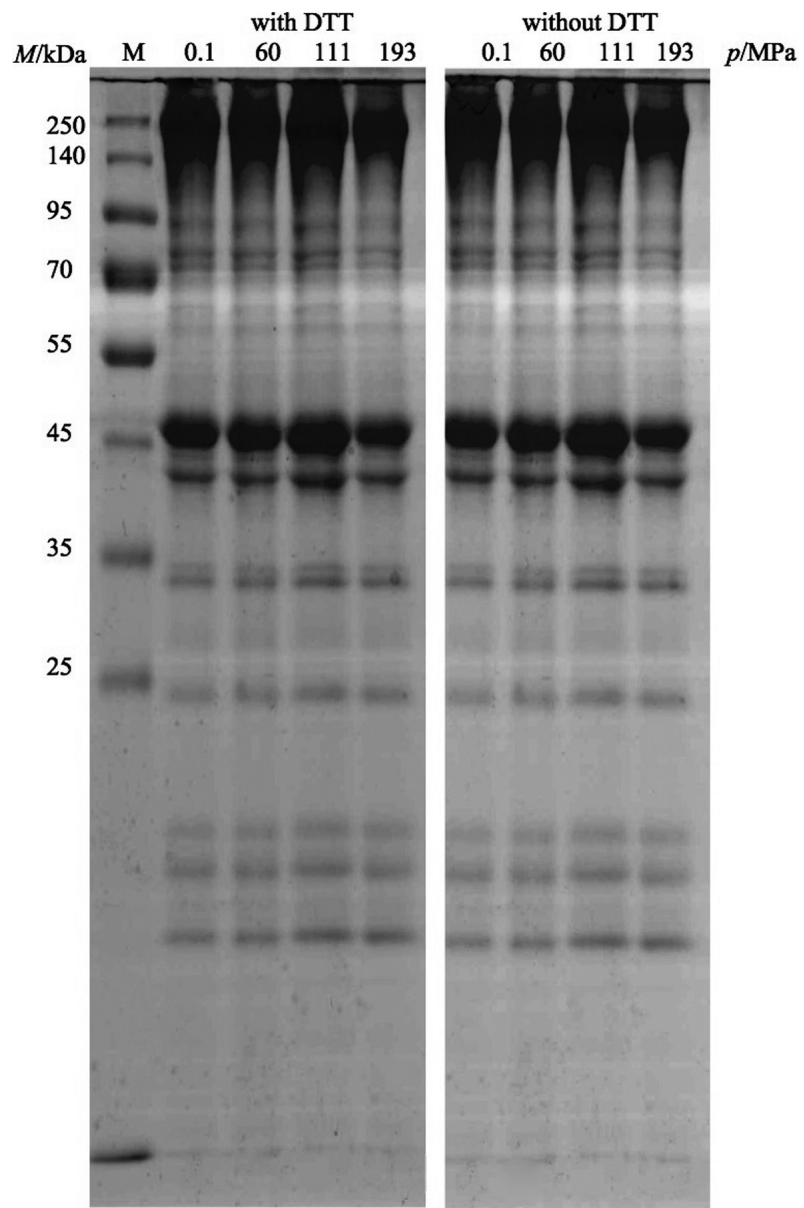

Fig. 4. SDS-PAGE profile of pressurized washed salmon meat proteins; $\mathrm{M}=$ markers, DTT=dithiothreitol

\section{Texture and gelling properties of washed fish meat}

The results of the texture profile analysis of fish gels are presented in Table 3. Pressurization of washed salmon and cod meat at subzero temperature induced gelation; however, hardness of the gels was lower by 28 and $26 \%$, respectively, than the hardness of the gels formed by heating. Better properties of heat-induced gels than those obtained by pressure treatment at $193 \mathrm{MPa}$ may be caused by setting step used only before heating. During this stage, crosslinking of the proteins by endogenous transglutaminase can take place, resulting in the formation of

Table 3. Texture profile analysis parameters of cod and salmon gels at $p=193 \mathrm{MPa}, t=-20^{\circ} \mathrm{C}$ and/or cooked at $t=90^{\circ} \mathrm{C}$ for $15 \mathrm{~min}$

\begin{tabular}{lcccc}
\hline Cod treatment & Hardness/N & Springiness & Cohesiveness & Chewiness \\
\hline A & $(33.3 \pm 2.1)^{\mathrm{a}}$ & $(0.90 \pm 0.03)^{\mathrm{a}}$ & $(0.80 \pm 0.07)^{\mathrm{a}}$ & $(27.4 \pm 5.3)^{\mathrm{a}}$ \\
B & $(46.1 \pm 1.5)^{\mathrm{b}}$ & $(0.90 \pm 0.04)^{\mathrm{a}}$ & $(0.70 \pm 0.09)^{\mathrm{a}}$ & $(31.9 \pm 8.8)^{\mathrm{b}}$ \\
C & $(64.9 \pm 3.9)^{\mathrm{c}}$ & $(0.90 \pm 0.01)^{\mathrm{a}}$ & $(0.70 \pm 0.05)^{\mathrm{a}}$ & $(45.7 \pm 23.1)^{\mathrm{c}}$ \\
\hline Salmon reatment & & & & \\
A & $(35.5 \pm 1.3)^{\mathrm{a}}$ & $(0.80 \pm 0.02)^{\mathrm{a}}$ & $(0.60 \pm 0.1)^{\mathrm{a}}$ & $(22.9 \pm 4.7)^{\mathrm{a}}$ \\
B & $(48.0 \pm 2.5)^{\mathrm{b}}$ & $(0.80 \pm 0.04)^{\mathrm{a}}$ & $(0.70 \pm 0.05)^{\mathrm{a}}$ & $(31.1 \pm 1.2)^{\mathrm{b}}$ \\
C & $(98.6 \pm 5.6)^{\mathrm{c}}$ & $(0.90 \pm 0.01)^{\mathrm{a}}$ & $(0.70 \pm 0.02)^{\mathrm{a}}$ & $(67.2 \pm 5.7)^{\mathrm{c}}$ \\
\hline
\end{tabular}

The results are expressed as mean value \pm S.D., $N=8$; values in a particular column followed by different letters differ significantly ( $\mathrm{p}<0.05) . \mathrm{A}=193 \mathrm{MPa} /-20^{\circ} \mathrm{C}, \mathrm{B}=90^{\circ} \mathrm{C} / 15 \mathrm{~min}, \mathrm{C}=193 \mathrm{MPa} /-20^{\circ} \mathrm{C}$, followed by $90^{\circ} \mathrm{C} / 15 \mathrm{~min}$ 
harder gels than the gels obtained by pressurization (37). Some authors also observed that pressurization of washed fish meat at $3-20{ }^{\circ} \mathrm{C}$ caused gelation, but their textural properties were worse than of gels obtained in the heat process without the setting step $(12,14,20,38)$. On the other hand, Uresti et al. (3) showed the opposite effect; the hardness of the gels formed by pressure treatment of unwashed arrowtooth flounder meat was higher than the hardness of the heated gels. Proteolytic enzymes from the muscles can be responsible for weaker mechanical properties of the heated samples. Uresti et al. (4) observed enzymatic degradation of proteins during incubation of paste from arrowtooth flounder meat at $60^{\circ} \mathrm{C}$. It is possible that in the samples of arrowtooth flounder meat cooked at $90^{\circ} \mathrm{C}$ some proteolysis of myofibrillar protein appeared before reaching this final temperature. Chung et al. (11) showed that when a protease inhibitor was present in the samples, the pressure-induced surimi gels from Pacific whiting (Merluccius productus) were characterized by lower shear stress and shear strain than the heat-induced gels. The differences in the reported data can also result from the parameters of the process. In the pressure range of $100-400 \mathrm{MPa}$, the properties of gels can be better than those obtained by heating; however, they can worsen with further increase in pressure $(7,14)$. The mechanical properties of gels also depend on a test used for their determination. The breaking force and deformation (puncture test) were higher in pressure-induced gels, while their hardness (compression test) was lower $(12,20,38)$. In our work, we observed the same direction of changes in the hardness and gelling strength. There was also a dependence between the hardness and the folding test. The pressure-induced gels from salmon and cod meat were characterized by lower hardness (Table 3 ) and lower value of the folding test (Table 4) than the gels formed in the thermal process.

Table 4. Cod and salmon gel strength and gel-forming ability

\begin{tabular}{lcc}
\hline Cod treatment & Gel strength/(N·mm) & Gel-forming ability \\
\hline A & $(69.8 \pm 1.4)^{\mathrm{a}}$ & B \\
B & $(81.8 \pm 1.0)^{\mathrm{b}}$ & A \\
C & $(177.1 \pm 16.3)^{\mathrm{c}}$ & AA \\
\hline Salmon treatment & Gel strength/(N.mm) & Gel-forming ability \\
\hline A & $(34.1 \pm 0.7)^{\mathrm{a}}$ & C \\
B & $(68.1 \pm 3.9)^{\mathrm{b}}$ & A \\
C & $(189.1 \pm 12.3)^{\mathrm{c}}$ & AA \\
\hline
\end{tabular}

The results are expressed as mean value \pm S.D., $N=8$; values followed by different letters differ significantly $(\mathrm{p}<0.05)$. $\mathrm{A}=193$ $\mathrm{MPa} /-20^{\circ} \mathrm{C}, \mathrm{B}=90^{\circ} \mathrm{C} / 15 \mathrm{~min}, \mathrm{C}=193 \mathrm{MPa} /-20^{\circ} \mathrm{C}$, followed by $90^{\circ} \mathrm{C} / 15 \mathrm{~min}$

The data on rheological properties of gels heated after pressure treatment are scarce. Gilleland et al. (17) reported that heat-induced surimi gels and gels from surimi pressurized before heating were characterized by similar tensile stress. However, this study showed that the hardness of gels from washed salmon and cod meat pressurized at $193 \mathrm{MPa}$ and $-20{ }^{\circ} \mathrm{C}$ and then heated was much higher than that of the gels from the only pressurized or only heated samples (Table 3). Uresti et al. $(3,4)$ reported that hardness of heat-induced arrowtooth flounder gels increased when pressurization was used prior to heating. This effect was higher at a pressure of 400 than of 600 $\mathrm{MPa}$. According to the authors, better molecular organization of gels is achieved at lower pressure and improvement of mechanical properties is possible after cooking of the samples.

The gels from pressurized and heated washed cod and salmon meat had the highest chewiness (Table 3). The springiness and cohesiveness of all samples were similar irrespective of the gel preparation conditions. The data presented in Table 4 also show that the pressurized and heated samples had the highest scores of the gel strength and folding test, while the gels induced only by pressure were characterized by the lowest values.

The mechanism leading to the formation of gels having improved rheological properties as a result of two processes: pressurization and heating, still remains unclear. Our research has shown that, similarly as at temperature above $0{ }^{\circ} \mathrm{C}$, pressurization at subzero temperature causes denaturation and depolymerization of myofibrilar proteins (Fig. 1 and Table 1) $(3,4,17)$. It has been hypothesized that these changes lead to opening up the structure of the protein and may result in a higher number of available locations on the substrate, which facilitated the active crosslinking of myosin (17). High pressure also increases the hydrophobicity and sulfhydryl content in actomyosin. This may be partially the reason for enhanced strength of the gels (10). Some authors suggested that pressure-induced denaturation and unfolding of meat proteins lead to exposition of reactive lysine and glutamine residues and facilitate formation of $\varepsilon-(\gamma$-glutamyl)lysine linkage by endogenous transglutaminase (39). Although many studies on the mechanism for inducing gelation of myofibrillar proteins by the pressure have already been carried out, many questions still remain unanswered. More research is needed to explain which changes in the proteins under high pressure are responsible for the enhancement of the thermal gelation of meat proteins.

\section{Conclusion}

The pressure treatment at subzero temperature of cod and salmon myofibrils suspended in diluted salt solution leads to the release of some myofibrillar proteins, but in the pressurized washed meat it leads to the loss of protein solubility in $0.9 \mathrm{M}$ salt solution. The disulphide bonds do not participate in denaturation/aggregation of proteins developed by moderate pressure at subzero temperature. The pressure treatment under these conditions induces gelation of washed cod and salmon meat; however, the hardness of the gels is lower than that of the gels formed in the thermal process. On the other hand, pressurization at subzero temperature before cooking allows the achievement of high synergistic effect in the increase of hardness of the gels and gelling strength.

\section{Acknowledgements}

This research project no. N N312 194033 was financed by the national research budget provided for the years 2007-2010. 


\section{References}

1. MacFarlane JJ, McKenzie IJ. Pressure-induced solubilization of myofibrillar proteins. J Food Sci. 1976;41:1442-6. https://doi.org/10.1111/j.1365-2621.1976.tb01191.x

2. Chevalier D, Sentissi M, Havet M, Le Bail A. Comparison of air-blast and pressure shift freezing on Norway lobster quality. J Food Sci. 2000;65:329-33. https://doi.org/10.1111/j.1365-2621.2000.tb16002.x

3. Uresti RM, Velazquez G, Ramírez JA, Vázquez M, Torres JA. Effect of high-pressure treatments on mechanical and functional properties of restructured products from arrowtooth flounder (Atheresthes stomias). J Sci Food Agric. 2004;84: 1741-9. https://doi.org/10.1002/jsfa.1876

4. Uresti RM, Velazquez G, Vázquez M, Ramírez JA, Torres JA. Effect of sugars and polyols on the functional and mechanical properties of pressure-treated arrowtooth flounder (Atheresthes stomias) proteins. Food Hydrocolloid. 2005;19:96473. https://doi.org/10.1016/j.foodhyd.2004.12.006

5. Fernández-Martín F, Cofrades S, Carballo J, Jiménez-Colmenero F. Salt and phosphate effects on the gelling process of pressure/heat treated pork batters. Meat Sci. 2002;61:15-23. https://doi.org/10.1016/S0309-1740(01)00157-7

6. Jiménez-Colmenero F, Cofrades S, Carballo J, Fernández P, Fernández-Martín F. Heating of chicken and pork meat batters under pressure conditions: protein interactions. J Agric Food Chem. 1998;46:4706-11. https://doi.org/10.1021/jf980354y

7. Ko WC, Jao CL, Hwang JS, Hsu KC. Effect of high-pressure treatment on processing quality of tilapia meat fillets. J Food Eng. 2006;77:1007-11. https://doi.org/10.1016/j.jfoodeng.2005.08.029

8. Jung S, de Lamballerie-Anton M, Ghoul M. Modifications of ultrastructure and myofibrillar proteins of post-rigor beef treated by high pressure. LWT - Food Sci Technol. 2000;33: 313-9. https://doi.org/10.1006/fstl.2000.0654

9. Cheftel JC, Culioli J. Effects of high pressure on meat: a review. Meat Sci. 1997;46:211-36. https://doi.org/10.1016/S0309-1740(97)00017-X

10. Ikeuchi $Y$, Tanji H, Kim K, Suzuki A. Dynamic rheological measurements on heat-induced pressurized actomyosin gels. J Agric Food Chem. 1992;40:1751-5. https://doi.org/10.1021/jf00022a005

11. Chung YC, Gebrehiwot A, Farkas DF, Morrissey MT. Gelation of surimi by high hydrostatic pressure. J Food Sci. 1994;59:523-4. https://doi.org/10.1111/j.1365-2621.1994.tb05553.x

12. Borderías AJ, Pérez-Mateos M, Solas M, Montero P. Frozen storage of high-pressure- and heat-induced gels of blue whiting (Micromesistius poutassou) muscle: rheological, chemical and ultrastructure studies. Z Lebensm Unters Forsch. 1997;2005:335-42. https://doi.org/10.1007/s002170050176

13. Pérez-Mateos M, Montero P. High-pressure-induced gel of sardine (Sardina pilchardus) washed mince as affected by pressure-time-temperature. J Food Sci. 1997;62:1183-8. https://doi.org/10.1111/j.1365-2621.1997.tb12240.x

14. Tabilo-Munizaga G, Barbosa-Cánovas GV. Color and textural parameters of pressurized and heat-treated surimi gels as affected by potato starch and egg white. Food Res Int. 2004; 37:767-75. https://doi.org/10.1016/j.foodres.2004.04.001

15. Okamoto M, Kawamura Y, Hayashi R. Application of high pressure to food processing: textural comparison of pressure- and heat-induced gels of food proteins. Agric Biol Chem.
1990;54:183-9.

https://doi.org/10.1080/00021369.1990.10869911

16. Montero P, Pérez-Mateos P, Borderías AJ. Chilled storage of high pressure and heat-induced gels of blue whithing (Micromesistius poutassou) muscle. Z Lebensm Unters Forsch. 1998;207:146-53.

https://doi.org/10.1007/s002170050309

17. Gilleland GM, Lanier TC, Hamann DD. Covalent bonding in pressure-induced fish protein gels. J Food Sci. 1997;62:71333.

https://doi.org/10.1111/j.1365-2621.1997.tb15442.x

18. Angsupanich K, Ledward DA. High pressure treatment effects on cod (Gadus morhua) muscle. Food Chem. 1998;63: 39-50.

https://doi.org/10.1016/S0308-8146(97)00234-3

19. Angsupanich K, Edde M, Ledward DA. Effects of high pressure on the myofibrillar proteins of cod and turkey muscle. J Agric Food Chem. 1999;47:92-9.

https://doi.org/10.1021/jf980587p

20. Pérez-Mateos M, Lourenço H, Montero P, Borderías AJ. Rheological and biochemical characteristic of high-pressure- and heat-induced gels from blue whiting (Micromesistius poutassou) muscle proteins. J Agric Food Chem. 1997;45:44-9. https://doi.org/10.1021/jf960185m

21. Sun XD, Holley RA. Factors influencing gel formation by myofibrillar proteins in muscle foods. Compr Rev Food Sci Food Saf. 2011;10:33-51. https://doi.org/10.1111/j.1541-4337.2010.00137.x

22. Montero P, López-Caballero ME, Pérez-Mateos M, Solas MT, Gómez-Guillén MC. Transglutaminase activity in pressure-induced gelation assisted by prior setting. Food Chem. 2005; 90:751-8. https://doi.org/10.1016/j.foodchem.2004.05.022

23. Malinowska-Pańczyk E, Walecka M, Pawłowicz R, Tylingo $\mathrm{R}$, Kołodziejska I. The effect of high pressure at subzero temperature on proteins solubility, drip loss and texture of fish (cod and salmon) and mammal's (pork and beef) meat. Food Sci Technol Int. 2014;20:383-95. https://doi.org/10.1177/1082013213488901

24. Gornall A, Bardawill CJ, David MM. Determination of serum proteins by means of the biuret reaction. J Biol Chem. 1949;177:751-66.

25. Bridgman PW. Water in the liquid and five solid forms under pressure. Proc Am Acad Arts Sci. 1912;47:441-558. https://doi.org/10.2307/20022754

26. Official Methods of Analysis. Rockville, MD, USA: AOAC International;1984.

27. Laemmli UK. Cleavage of structural proteins during the assembly of the head of bacteriophage T4. Nature. 1970;227: 680-5. https://doi.org/10.1038/227680a0

28. Bourne MC. Texture profile analysis. Food Technol. 1978; 32:62-6.

29. Mochizuki Y. Texture profile analysis. In: Wrolstad RE, Acree TE, An H, Decker EA, Penner MH, Reid DS, et al., editors. Current protocols in food analytical chemistry. New York, NY, USA: John Wiley \& Sons Inc.; 2001. pp. H2.3.1-7.

30. Lee CM. Surimi process technology: mechanically deboned, washed, and stabilized fish flesh is being increasingly used as a functional ingredient in fabricated seafood. Food Technol. 1984;11:69-80.

31. STATISTICA v. 8.0, StatSoft, Inc, Tulsa, OK, USA; 2007. Available from: http://www.statsoft.pl.

32. Suzuki A, Suzuki N, Ikeuchi Y, Saito M. Effects of high pressure treatment on the ultrastructure and solubilization of isolated myofibrils. Agric Biol Chem. 1991;55:2467-73. https://doi.org/10.1080/00021369.1991.10871015 
33. McArthur AJ, Wilding P. The effect of high pressure on skeletal muscle myofibrils and myosin. Prog Biotechnol. 1996; 13:323-6.

https://doi.org/10.1016/S0921-0423(06)80053-5

34. Chapleau NJ, de Lamballerie-Anton MI. Changes in myofibrillar proteins interactions and rheological properties induced by high-pressure processing. Eur Food Res Technol. 2003;216:470-6. https://doi.org/10.1007/s00217-003-0684-5

35. Ashie INA, Lanier TC, MacDonald GA. Pressure-induced denaturation of muscle proteins and its prevention by sugars and polyols. J Food Sci. 1999;64:818-22. https://doi.org/10.1111/j.1365-2621.1999.tb15919.x

36. Tan FJ, Lai KM, Hsu KC. A comparative study on physical properties and chemical interactions of gels from tilapia meat pastes induced by heat and pressure. J Texture Stud. 2010;41: 153-70. https://doi.org/10.1111/j.1745-4603.2010.00219.x

37. An H, Peters MY, Seymour TA. Roles of endogenous enzymes in surimi gelation. Trends Food Sci Technol. 1996;7: 321-7. https://doi.org/10.1016/0924-2244(96)10035-2

38. Fernández-Martín F, Pérez-Mateos M, Montero P. Effect of pressure/heat combinations on blue whiting (Micromesistius poutassou) washed mince: thermal and mechanical properties. J Agric Food Chem. 1998;46:3257-64. https://doi.org/10.1021/jf980040a

39. Ma XS, Yi SM, Yu YM, Li JR, Chen JR. Changes in gel properties and water properties of Nemipterus virgatus surimi gel induced by high-pressure processing. LWT - Food Sci Technol. 2015;61:377-84. https://doi.org/10.1016/j.lwt.2014.12.041 